\title{
Atyid Shrimps Production and Biomass Turnover in Masanga Mabe Equatorial Rain-Forest Stream of Congo Basin (Kisangani, DR Congo)
}

\author{
Alidor Busanga Kankonda ${ }^{1}$, Ali-Patho Ulyel ${ }^{1}$ and Nathan Utshiudienyema Nyongombe ${ }^{2}$ \\ 1. Department of Hydrobiology, University of Kisangani, Kisangani, Democratic Republic of Congo \\ 2. Department of Animal Sciences, National Educational University, Kinshasa, Democratic Republic of Congo
}

\begin{abstract}
Decapod crustaceans are one of the dominant faunal components of most tropical streams. However, several aspects concerning their biology and ecology are poorly known, especially in intertropical Africa. The aim of this study was to investigate the production of the atyid shrimps in Masanga Mabe, an equatorial lowland forest stream of Kisangani region. Samplings were undertaken biweekly from September 2000 to August 2003 with Surber net in four study sites. A total of 14,878 atyid shrimps specimens were sampled, measured for carapace length, weighted and identified. Atyid production was estimated by size frequency method according to sites (1,2 and 3). Atyid composition showed the existence of two species: C. africana (Caridina africana) Kingsley 1882 and C. togoensis (Caridina togoensis) Hilgendorf 1893. Specific production ranged from $1.35 \mathrm{~g} \cdot \mathrm{DM} \cdot \mathrm{m}^{-2} \cdot \mathrm{year}^{-1}(\mathrm{grams}$ dry mass per square meter per year) to $8.4 \mathrm{~g} \cdot \mathrm{DM} \cdot \mathrm{m}^{-2} \cdot \mathrm{year}^{-1}$ for $C$. africana and $0.95 \mathrm{~g} \cdot \mathrm{DM} \cdot \mathrm{m}^{-2} \cdot \mathrm{year}^{-1}$ to $4.55 \mathrm{~g} \cdot \mathrm{DM} \cdot \mathrm{m}^{-2} \cdot \mathrm{year}{ }^{-1}$ for $C$. togoensis. Mean annual $P / B$ ratios varied from 3.89 year $^{-1}$ to 4.37 year $^{-1}$ for $C$. africana and from 3.83 year $^{-1}$ to 3.98 year ${ }^{-1}$ for $C$. togoensis.
\end{abstract}

Key words: Atyid shrimps, equatorial stream, secondary production, Kisangani.

\section{Introduction}

Decapods are clearly visible and extensively widespread elements of the tropical freshwater communities [1-6] where they can play the same role that of Amphipods and Isopods in the temperate regions $[2,7,8]$. Thus, they can be considered like one of the most important groups of the tropical rivers [6].

They form an important proportion of the benthic biomass of the tropical rivers [9-11] and their behavior as detritivorous, omnivorous or predatory can affect directly or indirectly the benthic communities as well as the functional processes like the organic debris decomposition [5, 6, 12-14]. Their presence and abundance are indicators of the integrity of the river and its riparian zone [4].

Quantifying the flux of energy through a population is fundamental to understand its role and its

Corresponding author: Alidor Busanga Kankonda, Ph.D., research field: aquatic invertebrates biodiversity. E-mail: kankonda2000@yaoo.fr. importance in a community. The secondary production, which integrates the density and the other parameters of the life cycle, is the best indication to measure the success of a population. The majority of studies concerning the production of the benthic invertebrates of freshwaters has especially been centered on the Insects. Only less than $5 \%$ of the evaluations of production inventoried by Benke [15] concerned the Crustaceans. Of these, more than $90 \%$ were dedicated to the Amphipods and Isopods that are supplanted by the Decapods in the tropical rivers.

In spite of their abundance and their potential ecological importance, research on the Decapods in Africa, notably in Democratic Republic of Congo, is limited mainly to the taxonomic investigations and it exists very few works on their ecology and biology

The aim of the study was the evaluation of annual secondary production of the Caridina populations and their biomass turnover according to the sites. 


\section{Study Area}

This study has been achieved in the Masanga Mabe stream of the Masako Forest Reserve (Fig. 1). The Masako Forest Reserve is situated to $15 \mathrm{~km}$ in the northeast of Kisangani on the former road leading from Kisangani to Buta. It is included in the big buckle formed by the Tshopo river at $500 \mathrm{~m}$ of altitude and $0^{\circ} 36^{\prime} \mathrm{N}$ and $25^{\circ} 13^{\prime} \mathrm{E}$ [16-18]. It has a surface of 2,105 ha. It has a climate that belongs in the Af type (hot and humid climate with an average temperature of the coldest month higher than $18^{\circ} \mathrm{C}$ and a rainfall distributed over the year) of the classification of Köppen-Trewartha [19].

The stream is entirely in the fallow zone and has a length of about $3.2 \mathrm{~km}$. Four study sites were selected according to longitudinal gradient.

\section{Material and Methods}

Samplings were undertaken biweekly from September 2000 to August 2003 with Surber net of $0.5 \mathrm{~mm}$ of mesh size, $33 \mathrm{~cm}$ of side of the horizontal setting and $55 \mathrm{~cm}$ of depth in four study sites selected according to longitudinal gradient $[20,21]$. Each sample took an exploited surface of $0.5445 \mathrm{~m}^{2}$ which took the major habitats of the station into account [22, 23].

A total of 14,878 atyid shrimps specimens were sampled, preserved in formalin $4 \%$, measured for carapace length [24, 25] using ocular micrometer, weighted with Sartorius balance of $0.01 \mathrm{~g}$ of precision and identified using keys of De Man [26], Monod [27] and Day et al. [28]. Atyid production and biomass turnover were estimated by size frequency method according to sites [15, 21, 29-31].

For permitting a comparison of the productions estimated in WM (wet weight) with those of the other authors expressed in other units, notably in DM (dry weight), the following equation (according to Benke [21], Wetzel [32] and Lindegaard [33]) allowing the conversion of a mass unit to another has been used:

$1 \mathrm{~g} \mathrm{DM}=6 \mathrm{~g} \mathrm{WM}=0.9 \mathrm{~g}$ AFDM (ash-free dry mass)

$$
=0.5 \mathrm{~g} \mathrm{C}=5 \mathrm{kcal}=21 \mathrm{~J}
$$

The SPSS software has been used to make different calculations [34].

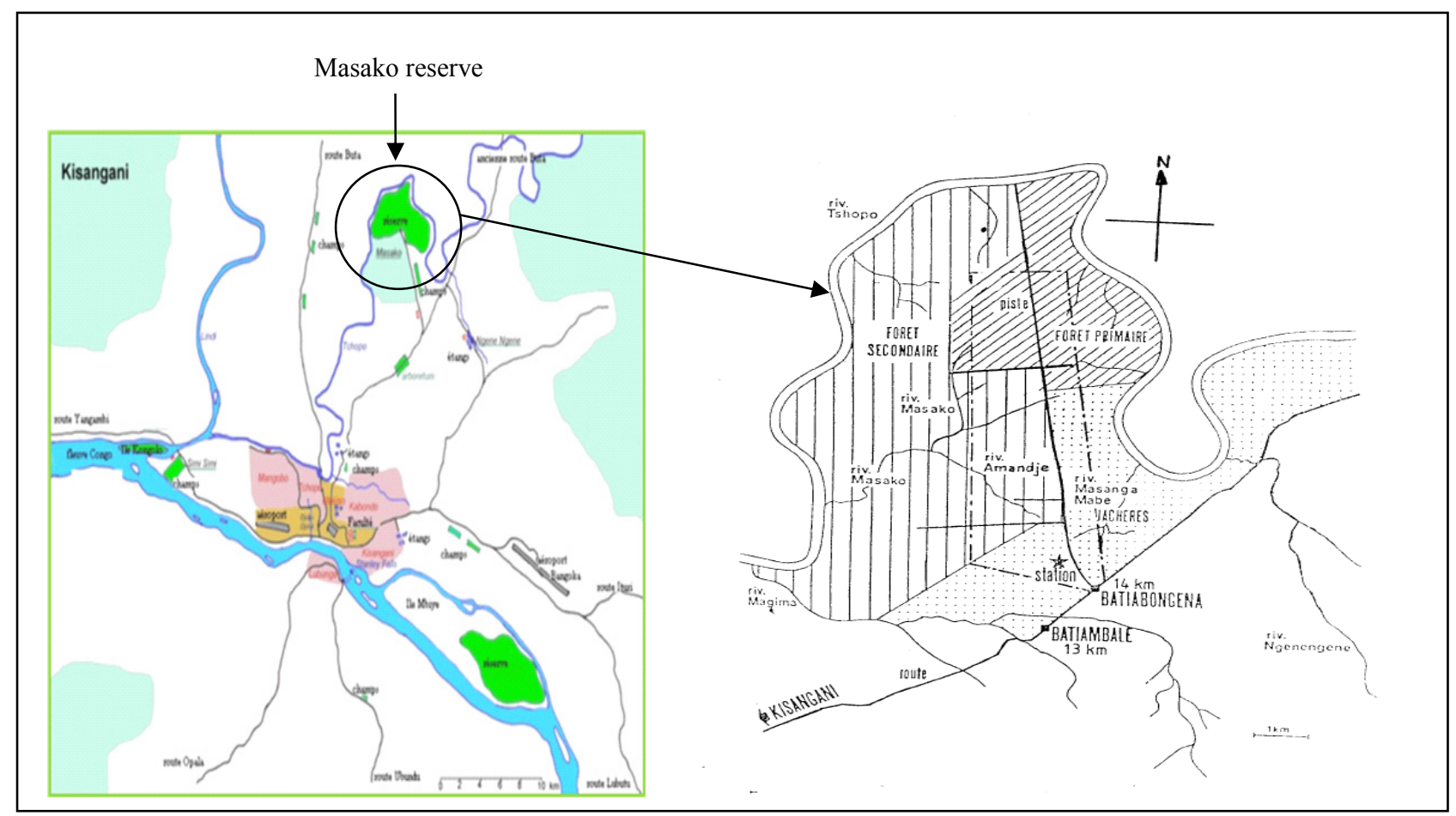

Fig. 1 Geographic position of Masako Forest Reserve and its hydrography. 


\section{Results}

Atyid composition showed the existence of two species: C. africana (Caridina africana) Kingsley 1882 and $C$. togoensis (Caridina togoensis) Hilgendorf 1893. Specific production ranged from $1.35 \mathrm{~g} \cdot \mathrm{DM} \cdot \mathrm{m}^{-2} \cdot$ year $^{-1}$ (grams dry mass per square meter per year) to $8.4 \mathrm{~g} \cdot \mathrm{DM} \cdot \mathrm{m}^{-2} \cdot \mathrm{year}^{-1}$ for C. africana and $0.95 \mathrm{~g} \cdot \mathrm{DM} \cdot \mathrm{m}^{-2} \cdot \mathrm{year}^{-1}$ to $4.55 \mathrm{~g} \cdot \mathrm{DM} \cdot \mathrm{m}^{-2} \cdot \mathrm{year}^{-1}$ for C. togoensis. Their intersite and annual variations ranked with those of density and biomass into the same species.

The highest values of secondary production have generally been observed in the station 3 that is situated upstream and the total production generally tends to increase from downstream to upstream (Table 1). The station 4 is not concerned by the analysis because of its very low number of shrimps.

Table 1 also shows that the production contribution of C. africana is generally the most important in each station during the whole period of survey.
The $P / B$ (production to biomass) ratio (or biomass turnover) observed varied from:

- 3.74 year $^{-1}$ to 4.72 year $^{-1}$ for $C$. africana with an annual average varying from 3.89 year $^{-1}$ (year 1) and 4.37 year $^{-1}$ (year 2);

- 3.22 year $^{-1}$ to 4.84 year $^{-1}$ for $C$. togoensis with an annual average varying from 3.83 year $^{-1}$ (year 3 ) to 3.98 year $^{-1}$ (year 2 ).

The biomass turnover varied within each species according to the stations and years (Table 2).

\section{Discussion}

Table 2 shows the intersite variations of the caridean production during the 3 years of observation. These variations go together with those of density and biomass of these two species. Dessaix [20] and Tumbiolo and Downing [35] affirm that the production is bound directly to the biomass. On his side, Benke [36] declares that the production can be raised because of a great biomass or a high $P / B$ ratio or to the two factors at a time. Yam and Dudgeon [14]

Table 1 Atyid production $\left(\mathrm{g} \cdot \mathrm{DM} \cdot \mathrm{m}^{-2} \cdot \mathrm{year}^{-1}\right)$ during the study years.

\begin{tabular}{|c|c|c|c|c|c|c|c|}
\hline \multirow{2}{*}{ Year } & \multirow{2}{*}{ Species } & \multicolumn{2}{|c|}{ Station 1} & \multicolumn{2}{|c|}{ Station 2} & \multicolumn{2}{|c|}{ Station 3} \\
\hline & & Value & $(\%)$ & Value & $(\%)$ & Value & $(\%)$ \\
\hline \multirow{3}{*}{1} & C. africana & 2.26 & 70.32 & 1.354 & 45.01 & 1.352 & 41.57 \\
\hline & C. togoensis & 0.954 & 29.68 & 1.654 & 54.99 & 1.90 & 58.43 \\
\hline & Total & 3.214 & & 3.008 & & 3.252 & \\
\hline \multirow{3}{*}{2} & C. africana & 4.434 & 73.53 & 2.988 & 43.35 & 8.49 & 65.11 \\
\hline & C. togoensis & 1.596 & 26.47 & 3.904 & 56.65 & 4.55 & 34.89 \\
\hline & Total & 6.03 & & 6.892 & & $1 ., 04$ & \\
\hline \multirow{3}{*}{3} & C. africana & 7.362 & 79.30 & 5.474 & 62.35 & 4.666 & 73.69 \\
\hline & C. togoensis & 1.922 & 20.70 & 3.306 & 37.65 & 1.666 & 26.31 \\
\hline & Total & 9.284 & & 8.78 & & 6.332 & \\
\hline
\end{tabular}

Table 2 Caridina $P / B$ ratios $\left(\right.$ year $^{-1}$ ) observed in Masanga Mabe stream.

\begin{tabular}{llllll}
\hline Year & Species & Station 1 & Station 2 & Station 3 & Average (standard deviation) \\
\hline \multirow{2}{*}{1} & C. africana & 4.05 & 3.76 & 3.86 & $3.89(0.15)$ \\
& C. togoensis & 4.11 & 3.5 & 4.03 & $3.88(0.33)$ \\
\multirow{2}{*}{2} & C. africana & 4.6 & 4.28 & 4.22 & $4.37(0.20)$ \\
& C. togoensis & 3.22 & 4.84 & 3.88 & $3.98(0.81)$ \\
\hline \multirow{2}{*}{3} & C. africana & 3.74 & 4.33 & 4.72 & $4.26(0.49)$ \\
& C. togoensis & 3.36 & 3.86 & 4.27 & $3.83(0.46)$ \\
\hline
\end{tabular}


observed that the caridean production in the forest streams of Hong Kong varied according to biomass and density.

The production estimated during the first year, for each of the species, is generally at least 2 times inferior to those of the second and third years which are similar. Actually, Dudgeon [37] declares that it can be a considerable interannual variation of the production within a same species. He has observed, for example, a variation of $8 \%$ to $537 \%$ for the eight species of collector Trichoptèra met in Hong Kong streams. Also, Dessaix [20] has observed that the first 2 years evaluations of production of Gammarus in the French Rhone were similar whereas the last cycle of survey presented values of production about 3.5 weak times. Mantel and Dudgeon [5] and Yam and Dudgeon [14] made the same report also while studying the production of Macrobranchium hainanenses and Caridina in the Hong Kong forest streams, respectively.

The production of the Caridina in Masanga Mabe stream is extensively dominated by the species $C$. africana. It would be bound mainly to densities and biomasses generally high explainable in particular by its high fertility and fast growth when compared to $C$. togoensis (personal observations).

The highest values have generally been observed at the station 3 that is situated upstream and the total production, generally, tends to increase from downstream to upstream. Actually, Winterbourn et al. [38] have observed also that the evaluations of production of Deleatidium sp., the most abundant insect of the streams of the western coast of South Island (New Zealand), presented a general decrease with the increase of the size of the river. The production was raised more in the smallest rivers. Tumbiolo and Downing [35] think that this reduction of production according to the downstream would be bound to the greatly negative effect of the depth on the production.

According to Wetzel [32], the most common values of annual production of macroinvertebrates would be situated between $0.1 \mathrm{~g} \cdot \mathrm{DM} \cdot \mathrm{m}^{-2} \cdot \mathrm{year}^{-1}$ and 1 $\mathrm{g} \cdot \mathrm{DM} \cdot \mathrm{m}^{-2} \cdot \mathrm{year}^{-1}$. The values observed in Masanga Mabe stream $\left(0.95-8.49 \mathrm{~g} \cdot \mathrm{DM} \cdot \mathrm{m}^{-2} \cdot \mathrm{year}^{-1}\right)$ are therefore generally a lot higher than the common values. This would be bound, contrary to the benthos of temperate region, to a long active growth period due to the water temperature that remains high ( $>$ $20{ }^{\circ} \mathrm{C}$ ) during whole year but also to the permanent availability of quality foods and in sufficient quantity. Actually, Benke [36] thinks that the quantity and the quality of foods constitute the most important limiting factors for the benthic production. Murphy et al. [39], Pringle et al. [40] and Dangles [41] affirm that the benthic accumulation of the allochthonous detritus in the forest headwaters streams is an important resource colonized by macroinvertebrates for eating and having shelter. Chadwick and Huryn [42] and Smock et al. [43], studying the role of the habitat in the determination of macrobenthic production, have concluded that the production was always high on the bottom rich in plant debris than that of sandy one.

Table 3 shows some values of caridean production estimated by the size frequency method in some lotic and lentic systems.

Table 3 shows that the data do not seem to depart from those observed elsewhere on the Caridina. These values are even sufficiently high for $C$. africana. But one is not able, as Yam and Dudgeon [14], to explain the substantial differences of production between the Caridina, but they reflect the disparity of the conditions to which these species are submitted in different habitats.

The analysis of Table 2 shows that the $P / B$ ratios observed are located in the interval of 3 year $^{-1}$ to 9 year $^{-1}$ for the shrimps which are univoltine species [15]. Concerning the variation of $P / B$ ratios, sometimes enormous, within a same species, Benke [36] thinks that it is bound to the particular environmental conditions to which is submitted a population, notably the types of habitats, the climate and other factors 
Table 3 Production values of some Caridina in different freshwater systems.

\begin{tabular}{llll}
\hline Species & Ecosystem & $\begin{array}{l}\text { Production } \\
\left(\mathrm{g} \cdot \mathrm{DM} \cdot \mathrm{m}^{-2} \cdot \mathrm{year}^{-1}\right)\end{array}$ & Reference \\
\hline Caridina nilotica & $\begin{array}{l}\text { Victoria Lake } \\
\text { (littoral zone) }\end{array}$ & 4.2 & Ignatow et al. [44] \\
Caridina nilotica & $\begin{array}{l}\text { Sibaya Lake } \\
\text { (littoral zone, South Africa) }\end{array}$ & 24.4 & Hart [3] \\
Caridina cantonensis & $\begin{array}{l}\text { Forest streams } \\
\text { (Hong Kong) }\end{array}$ & $\begin{array}{l}\text { Forest streams } \\
\text { (Hong Kong) }\end{array}$ & Yam and Dudgeon [14] \\
Caridina serrata & $\begin{array}{l}\text { Masanga Mabe stream } \\
\text { (Kisangani) }\end{array}$ & $1.18-1.33$ & Yam and Dudgeon [14] \\
C. africana & $\begin{array}{l}\text { Masanga Mabe stream } \\
\text { (Kisangani) }\end{array}$ & $0.95-4.55$ & This study \\
C. togoensis & & & This study \\
\hline
\end{tabular}

Table 4 Some Caridina $P / B$ ratios estimated in different freshwater systems.

\begin{tabular}{llll}
\hline Species & Ecosystem & $P / B\left(\right.$ year $\left.^{-1}\right)$ & Reference \\
\hline C. cantonensis & $\begin{array}{l}\text { Forest streams } \\
\text { (Hong Kong) }\end{array}$ & $2.02-3.89$ & Yam and Dudgeon \\
C. serrata & $\begin{array}{l}\text { Forest streams } \\
\text { (Hong Kong) }\end{array}$ & $2.92-3.17$ & Yam and Dudgeon \\
C. africana & $\begin{array}{l}\text { Masanga Mabe stream } \\
\text { (Kisangani) }\end{array}$ & $3.89-4.37$ & This study \\
C. togoensis & $\begin{array}{l}\text { Masanga Mabe stream } \\
\text { (Kisangani) }\end{array}$ & $3.83-3.88$ & This study \\
\hline
\end{tabular}

that act on and regulate the population.

Table 4 shows some values of Caridina $P / B$ ratios estimated by the size frequency method in some lotic and lentic systems.

The analysis of Table 4 shows that the values of the caridean biomass turnover found in Kisangani (3.83-4.37 year $^{-1}$ ) are higher than those observed elsewhere on other Caridina (2.02-3.86 year ${ }^{-1}$ ). Indeed, Wetzel [32] affirms that the production by unit of biomass generally increases with the reduction of the latitude following the elongation of the season of the active growth.

\section{Conclusions}

The intersite variations of the Caridina production in Masanga Mabe stream during the 3 years of observation go together with those of density and biomass of these two species ( $C$. africana and $C$. togoensis).

This production is dominated extensively by $C$. africana and varied from $1.35 \mathrm{~g} \cdot \mathrm{DM} \cdot \mathrm{m}^{-2} \cdot \mathrm{year}^{-1}$ to 8.49 $\mathrm{g} \cdot \mathrm{DM} \cdot \mathrm{m}^{-2} \cdot \mathrm{year}^{-1}$ for $C$. africana and from 0.95 $\mathrm{g} \cdot \mathrm{DM} \cdot \mathrm{m}^{-2} \cdot \mathrm{year}^{-1}$ to $4.55 \mathrm{~g} \cdot \mathrm{DM} \cdot \mathrm{m}^{-2} \cdot \mathrm{year}^{-1}$ for $C$. togoensis. The highest values of production have generally been observed in the station 3 that is situated upstream and the total production generally tends to increase from downstream to upstream.

The values of secondary production observed in Masangamabe stream $\left(0.95-8.49 \mathrm{~g} \cdot \mathrm{DM} \cdot \mathrm{m}^{-2} \cdot \mathrm{year}^{-1}\right)$ are generally a lot higher than the common values of production of macroinvertebrates situated between 0.1 $\mathrm{g} \cdot \mathrm{DM} \cdot \mathrm{m}^{-2} \cdot$ year $^{-1}$ and $1 \mathrm{~g} \cdot \mathrm{DM} \cdot \mathrm{m}^{-2} \cdot$ year $^{-1}[33]$. However, these data do not seem to depart from those observed elsewhere on the Caridina $[3,14,44]$.

The average $P / B$ ratio varies from 3.89 year $^{-1}$ to 4.37 year $^{-1}$ for $C$. africana and from 3.83 year $^{-1}$ to 3.98 year $^{-1}$ for $C$. togoensis. These ratios are therefore sufficiently high for these Caridina that are univoltine species and are located in the interval of 3 year $^{-1}$ to 9 year $^{-1}$.

The values of Caridina biomass turnover found in Kisangani (3.83-4.37 year $^{-1}$ ) are higher than those observed in the forest streams of Hong Kong [14]. 


\section{Acknowledgments}

The present work was supported in part by the BTC (Belgian Technical Co-operation). The authors thank the Laboratory of Hydrobiology and Aquaculture team (Richard Mahamba, Jacob Ndjaki, Ernest Tambwe...) for the help on field data collection and in the laboratory analysis. The authors are grateful to anonymous refrees for constructive comments on the manuscript..

\section{References}

[1] Crowl, T. A., Bouwer, N., Townsend, M. J., Covich, A. P., and Scatena, F. N. 2000. "Estimating the Potential Role of Freshwater Shrimp on an Aquatic Insect Assemblage in a Tropical Headwater Stream: A Bioenergetics Approach." Verh. Internat. Verein. Limnol 27: 2403-7.

[2] Fossati, O., Mosseron, M., and Keith, P. 2002. "Distribution and Habitat Utilisation in Two Atyid Shrimps (Crustacea: Decapoda) in Rivers of Nuku-Hiva Island (French Polynesia)." Hydrobiologia 472: 197-206.

[3] Hart, R. C. 1981. "Population Dynamics and Production of the Tropical Freshwater Shrimp Caridina nilotica (Decapoda: Atyidae) in the Littoral of Lake Sibaya." Freshwater Biology 11: 531-47.

[4] Iwata, T., Inoue, M., Nakano, S., Miyasaka, H., Doi, A., and Covich, A. P. 2003. "Shrimp Abundance and Habitat Relationships in Tropical Rain-Forest Streams, Sarawak, Borneo.” Journal of Tropical Ecology 19: 387-95.

[5] Mantel, K., and Dudgeon, D. 2004. "Growth and Production of a Tropical Predatory Shrimp, Macrobrachium hainanensis (Palaemonidae), in Two Hong Kong streams.” Freshwater Biology 49: 1320-36.

[6] Pringle, C. M., Blake, G. A., Covich, A. P., Buzby, K. M., and Finley, A. 1993. "Effects of Omnivorous Shrimp in a Montane Tropical Stream: Sediment Removal, Disturbance of Sessile Invertebrates and Enhancement of Understory Algal Biomass.” Oecologia 93: 1-11.

[7] Covich, A. P. 1988. "Atyid Shrimp in the Headwaters of the Luquillo Mountains Puerto-Rico: Filter Feeding in Natural and Artificial Streams." Verh. Internat. Verein. Limnol. 23: 2108-13.

[8] De Silva, P. K., and De Silva, K. H. G. M. 1989. "Aspects of the Population Ecology of a Tropical Freshwater Atyid Shrimp Caridina fernadoi ARUD, and COSTA, 1962 (Crustacea: Decapoda: Atyidae)." Archiv für Hydrobiologie 117: 237-53.

[9] Bright, G. R. 1982. "Secondary Benthic Production in a Tropical Island Stream." Limnol. and Oceanography 27:
472-80.

[10] Ramirez, A., Paaby, P., Pringle, C. M., and Agüero, G. 1998. "Effect of Habitat Type on Benthic Macroinvertebrates in Two Lowland Tropical Streams, Costa Rica." Revista de Biologia Tropical 46 (suppl. 6): 201-13.

[11] Ramirez, A., and Pringle, C. M. 1998. "Structure and Production of a Benthic Insect Assemblage in a Neotropical Stream." J. N. Amer. Benthol. Soc. 17: 443-63.

[12] Crowl, T. A., Mcdowell, W. H., Covich, A. P., and Johnson, S. L. 2001. "Freshwater Shrimp Effects on Detrital Processing and Nutrients in a Tropical Headwater Stream.” Ecology 82: 775-83.

[13] Pringle, C. M., and Hamazaki, T. 1998. "The Role of Omnivory in a Neotropical Stream: Separating Diurnal and Nocturnal Effects." Ecology 79: 269-80.

[14] Yam, R. S. W., and Dudgeon, D. 2006. "Production Dynamics and Growth of Atyid Shrimps (Decapoda: Caridina spp.) in 4 Hong Kong Streams: The Effects of Site, Season and Species." J. N. Amer. Benthol. Soc. 25 (2): 406-16.

[15] Benke, A. C. 1993. "Concepts and Patterns of Invertebrate Production in Running Waters." Verh. Internat. Verein. Limnol. 25: 15-38.

[16] Dudu, A. M. 1991. "Community Study of Insectivores and Rodents of Lowland Rain-Forest of Zaïre (Kisangani, Masako)." Ph.D. thesis, University of Antwerp.

[17] Ifuta, N. B. 1993. "Ecological and Hormonal Parameters during the Grow and the Reproduction of Epomops franqueti (Mammalia) (Zaïre)." Ph.D. thesis, Katholic University of Leuven.

[18] Upoki, A. 2001. "Bulbul Community Study (Pycnonotidae, Passeriformes) of Masako Forest Reserve (D. R. Congo)." Ph.D. thesis, University of Kisangani.

[19] Bultot, F., and Griffths, J. F. 1972. "The Equatorial Wet Zone." In World Survey of Climatology vol. 10: Climates of Africa, edited by Griffiths, J. F. Amsterdam-London-New York: Elsevier.

[20] Dessaix, J. 1986. "Structure and Dynamics of the French Upper Rhone Ecosystems 28. Production Estimation of Gammarids.” Arch. Hydrobiol. 107 (1): 125-41.

[21] Benke, A. C. 1996. "Secondary Production of Macroinvertebrates." In Methods on Stream Ecology, edited by Hauer, F. R., and Lamberti, G. A. San Diego: Academic Press.

[22] Hawkins, C. P., and Sedell, J. R. 1981. "Longitudinal and Seasonal Changes in Functional Organization of Macroinvertebrate Communities in Four Oregon Streams.” Ecology 62 (2): 387-97.

[23] Cariss, H., and Pretty, J. L. 2000. "Comparing Diurnal and Nocturnal Cased Caddis Activity in an Upland 


\section{Atyid Shrimps Production and Biomass Turnover in Masanga Mabe Equatorial Rain-Forest Stream of Congo Basin (Kisangani, DR Congo)}

Stream." Verh. Internat. Verein. Limnol. 27: 942.

[24] Byrne, C. F., Lynch, J. M., and Bracken, J. J. 1999. “A Sampling Strategy of Stream Populations of White-Clawed Crayfish, Austropotamobius pallipes (Lereboullet), (Crustacea, Attacidae)." Biol. Environ.: Proc. R. Ir Acad. 99 B (2): 89-94.

[25] Storey, A. W., Tenakanai, C. D., Bakowa, A., Maie, A. Y., Swales, S., and Short, J. W. 2000. "Distribution and Reproductive Strategies of Macrobranchium Prawns (Decapoda, Caridea, Paleomonidae) in the Fly River System Papua New Guinea, with Observations on Possible Mining Impacts.” Verh. Internat. Verein. Limnol. 27: 993-1002.

[26] De Man, J. G. 1925. "Contribution to the Study of Marine and Fluviatile Macroure Decapods of the Belgian Congo Basin.” Ann. Mus. Congo Belge Zool. Série III (Arthropodes), Section III (Crustacés) 1: 1-54.

[27] Monod, T. 1980. "Decapods." In Aquatic Flora et Fauna of Sahelo-soudanian Africa. Volume I, edited by Durand, J. R., and Leveque, C. Paris: Overseas Agency for Scientific and Technical Research.

[28] Days, J. A., Stewart, B. A., De Moor, U., and Louw, A. E. 2001. Guide to the Freshwaters Invertebrates of Southern Africa. Vol. 4. Crustaceae III. Water research commission report.

[29] Hynes, H. B., and Coleman, M. J. 1968. "A Simple Method of Assessing the Annual Production of Stream Benthos." Limnol. Oceanogr. 13: 569-73.

[30] Hamilton, A. L. 1969. "On Estimating Annual Production.” Limnol. Oceanogr. 14: 771-82.

[31] Benke, A. C. 1976. "Dragonfly Production and Prey Turnover." Ecology 57: 915- 27.

[32] Wetzel, R. G. 1983. Limnology. 2nd ed.. New York: Sounders College Publishing.

[33] Lindegaard, C. 1992. "Zoobenthos Ecology of Thingvallavatn: Vertical Distribution, Abundance, Population Dynamics and Production." Oïkos 64: 227-304.

[34] Nie, N. H., Hull, J. G., Jenkiness, C. H., Steinbienner, K., and Bent, D. H. 2003. Statistical Package for Social Sciences (SPSS). New York: Mc Graw-Hill.
[35] Tumbiolo, M. L., and Downing, J. A. 1994. "An Empirical Model for the Prediction of Secondary Production in Marine Benthic Invertebrate Population." Mar. Ecol. Prog. Ser. 114: 165-74.

[36] Benke, A. C. 1984. "Secondary Production of Aquatic Insects." In Ecology of Aquatic Insects, edited by Resh, V. H., and Rosenberg, D. M. New York: Praeger.

[37] Dudgeon, D. 2000. "The Ecology of Tropical Asian Rivers and Streams in Relation to Biodiversity Conservation.” Annu. Rev. Ecol. Syst. 31: 239-63.

[38] Winterbourn, M. J., Collier, K. J., and Craesser, A. K. 1988. "Ecology of Small Streams on the West Coast of the South Island, New Zealand." Verh. Internat. Verein. Limnol. 23: 1427-31.

[39] Murphy, J. F., Griller, P. S., and Horan, M. A. 1998. "Spatial Scale and the Aggregation of Stream Macroinvertebrates Associated with Leaf Packs." Freshwater Biology 39: 325-37.

[40] Pringle, V. M., Naiman, R. J., Bretschko, G., Karr, J. R., Oswood, M. W., Webster, J. R., Welcomme, R. L., and Winterbourn, M. 1988. "Patch Dynamics in Lotic Systems: The Stream as a Mosaic." N. Am. Benthol. Soc. 7 (4): 503-24.

[41] Dangles, O. 2002. "Aggregation of Shredder Invertebrates Associated with Benthic Detritus Pools in Seven Headwater Forested Streams." Verh. Internat. Verein. Limnol. 28 (2): 910-3.

[42] Chadwick, M. A., and Huryn, A. D. 2007. "Role of Habitat in Determining Macroinvertebrate Production in an Intermittent Stream System." Freshwater Biology 52 (2): 240-51.

[43] Smock, L. A., Gladden, J. E., Riekenberg, J. L., Smith, L. C., and Black, C. E. 1992. "Lotic Macroinvertebrate Production in Three Dimensions: Channel Surface, Hyporheic, and Floodplain Environments." Ecology 73: 876-86.

[44] Ignatow, M., Mbahizireki, G., and Lehman, J. T. 1996. "Secondary Production and Energetics of the Shrimp Caridina nilotica in Lake Victoria, East Africa: Model Development and Application." Hydrobiologia 332: 175-81. 